\title{
Sperm Quality and Testicular Histomorphometry of Wistar Rats Supplemented with Extract and Fractions of Fruit of Tribulus terrestris $\mathbf{L}$.
}

\author{
Nelma Neylanne Pinho Muniz Oliveira ${ }^{1}$, Matheus Augusto Rodrigues Félix ${ }^{2}$, Tauany Costa \\ Silva Pereira ${ }^{2}$, Luiz Gustavo Pessoa Rocha ${ }^{2}$, José Rafael Miranda ${ }^{2}$, Márcio Gilberto \\ Zangeronimo $^{2}$, José Eduardo Brasil Pereira Pinto ${ }^{1}$, Suzan Kelly Vilela Bertolucci ${ }^{1}$ and \\ Raimundo Vicente de Sousa ${ }^{2 *}$ \\ 1Departamento de Agricultura; Universidade Federal de Lavras; Lavras - MG - Brasil. 2Departamento de \\ Medicina Veterinária; Universidade Federal de Lavras; Lavras - MG-Brasil
}

\begin{abstract}
The aim of this study was to assess the sperm quality and testicular histomorphometry of Wistar rats supplemented with extract and fractions of fruits of Tribulus terrestris L. The ethanolic extract was obtained by dynamic maceration of spray-dried fruit. This extract was fractionated by liquid-liquid partition, using increasing polarity solvents. Twenty male rats were separated in four groups, with five rats in each group. The control was supplemented with distilled water, while the others were daily given the ethanolic extract, hexanic or aqueous fraction soluble in methanol in a dose of $42 \mathrm{mg} \mathrm{kg}^{-1}$.day for 70 days. Sperm was obtained from the right epididymal tail for the analysis of motility, count, morphology and viability. The testicular weight of groups supplemented with ethanolic extract and aqueous fraction soluble in methanol was higher when compared to the control. The gonadosomatic index increased in the group supplemented with ethanolic extract. The nuclear, cytoplasmic and individual volume of Leydig cells increased in supplementation with hexanic and aqueous fractions soluble in methanol. It was concluded that the extract influenced the spermatogenesis, while hexanic and aqueous fractions soluble in methanol promoted the changes in the intertubular compartment. Therefore, Tribulus terrestris did not improve the sperm quality of the rats.
\end{abstract}

Key words: Vegetal extract, Spermatogenesis, Leydig cells

\section{INTRODUCTION}

The infertility rate is a global problem affecting an average of 8 to $12 \%$ of human's couples. The low concentration of spermatozoa is a major cause of male infertility (Sellandi et al. 2012).The mammalian testis is a sensitive organ to the use of toxic substances that may affect spermatogenesis leading to changes in semen quality and fertility(Pannocchia et al. 2008). Tribulus terrestris L., popularly known by various names such as tribulus, natural viagra, puncture vine, thorn three points, devil's thorn, yellow vine. Bull's head is a plant of Zygophyllaceae family from India but widely distributed in warm regions around the world (Kostova and Dinchev 2005; Hammoda et al. 2013). In traditional Chinese and Indian medicine, the fruit is used in the treatment of infertility, impotence, erectile dysfunction and low libido (Gauthaman et al. 2002; Gauthaman and Ganesan 2008; Singh and Gupta 2011). Phytochemical studies have shown the presence of

*Author for correspondence: rvsousa@dmv.ufla.br 
several compounds in ethanolic, hexanic and methanolic extracts of $T$. terrestris such as steroidal saponins, flavonoids and alkaloids (Bedir and Khan 2000; Dinchev et al. 2008; Su et al. 2009).

Some studies have assessed the effect of $T$. terrestris administration on male reproductive system and showed that the plant could positively influence on spermatogenesis (Bashir et al. 2009; Elahi et al. 2013; Keshtmand et al. 2014). Andrade et al. (2010) founded a positive effect on sperm production in male Wistar rats by the administration of three doses of 11,42 and 110 mg. $\mathrm{kg}^{-1} \cdot \mathrm{day}^{-1}$ of $T$. terrestris. However, some studies have contradicted these effects, showing no effects when administered the herbal extracts or preparations from this species. Neychev and Mitev (2005)found that $T$. terrestris was not able to increase the levels of androgenic hormones in young humans. Thus, the results involving the effectiveness of this plant are still uncertain and controversial.

Considering its popular application and incipient studies of the reproduction area, the aim of this study was to assess the sperm quality and testicular histomorphometry of Wistar rats supplemented with the extract and fractions of fruits of $T$. terrestris $\mathrm{L}$.

\section{MATERIAL AND METHODS}

\section{Preparation of the extract and fractions}

Dried fruits of $T$. terrestris L. were purchased from the Pharmaceutical Industry Catedral, Vespasiano, Minas Gerais, Brazil. The fruit (2.922 g) was sprayed on the knives mill (Marconi ${ }^{\circledR}$, model MA-680). The extract was obtained by the dynamic maceration in large mouthed amber bottles kept under constant agitation in an orbital shaker (Gio Gyrotory®) on $164 \mathrm{rpm}$. The dried plant material was fractionated in portions about $250 \mathrm{~g}$ and extracted with $500 \mathrm{~mL}$ of commercial ethanol $92^{\circ}$ INPM). For the depletion of vegetable drugs, 10 cycles of extraction were conducted in which every seven days, the extract was filtered and the plant material was macerated with fresh solvent. The extract was dried in a rotary evaporator under reduced pressure at $40 \pm 2^{\circ} \mathrm{C}$ and then kept in a desiccator under vacuum to dryness. The crude ethanolic extract (219.45 g) was stored at $-18 \pm 2{ }^{\circ} \mathrm{C}$ until the bioassay.
An aliquot of $164.59 \mathrm{~g}$ of ethanolic extract was fractionated by liquid-liquid partition. The ethanolic extract was re-suspended in distilled water in two separate hoppers (approximately 900 $\mathrm{mL}$ in each hopper) and partitioned with sequential portions (approximately $3 \times 300 \mathrm{~mL}$ ) of $n$-hexane (Hex), dichloromethane (DCM), ethyl acetate $(\mathrm{EtOAc})$ and $n$-butanol $(\mathrm{BuOH})$. Methanol $(\mathrm{MeOH})$ was added to the aqueous fraction (AQ) and the aqueous soluble fraction in methanol (AQsol) and insoluble (AQinsol) were separated. Each fraction was dried, on rotary evaporator under reduced pressure at $40 \pm 2^{\circ} \mathrm{C}$. Then, kept in a desiccator under vacuum to dryness. The AQinsol fraction was submitted to freeze-drying (SpeedVac Integrated System, Model L 101, Liobras mark). All the fractions were stored at -18 $\pm 2^{\circ} \mathrm{C}$ until the bioassay.

\section{Animal treatments}

The experiment was approved by the Ethics Committee on Animal Use (CEUA) of Federal University of Lavras, under the protocol $\mathrm{n}^{\circ}$ 027/14. Twenty male Wistar rats, Rattus norvegicus ( $\mathrm{n}=5$ /group) approximately 60 days of age and weight of $295 \pm 28 \mathrm{~g}$ were obtained from the Central Animal Facility of Federal University of Lavras(UFLA). The animals were individually placed in the metabolic cages for seven days for acclimatization. Throughout the trial period, the animals were kept in an environment with controlled temperature of $\pm 23^{\circ} \mathrm{C}$ and light cycle $12 / 12 \mathrm{~h}$. The animals received commercial rodent chow and water ad libitum.

The animals were randomly distributed in four experimental groups with five animals in each group: control group $\left(\mathrm{G}_{1}\right)$ was treated with distilled water and the remaining groups $\left(\mathrm{G}_{2}, \mathrm{G}_{3}\right.$ and $\mathrm{G}_{4}$ ) received a single dose of $42 \mathrm{mg} \cdot \mathrm{kg}^{-1}$. day ${ }^{1}$ of the ethanol extract or hexanic or aqueous soluble in methanol fractions, respectively. The dicloromethanic, ethyl acetate, $n$-butanol and aqueous insoluble in methanol fractions were not utilized in this study. The single dose given was determined in accordance with Andrade et al. (2010). For administration, the extract and aqueous insoluble in methanol fraction were diluted in distilled water and hexanic fraction in mineral oil.

The animals were submitted to daily gavage for 70 days and weighed every seven days. At the end of the experiment and after $12 \mathrm{~h}$, the animals were anaesthetized intraperitoneal with sodium 
pentobarbital (80 mg. $\mathrm{kg}^{-1}$ ) and euthanized by exsanguination after cardiac puncture. Then, the animals were submitted to the wide opening of the abdominal cavity to expose the reproductive organs that were collected and weighed.

\section{Gonadosomatic index}

Based on the body and testicular weight, gonadosomatic index (GSI) was calculated from the formula GSI $=$ [Gonads weight $(\mathrm{g}) /$ Body weight $(\mathrm{g})]^{* 100}$ (AMANN, 1970).

\section{Morphometric analysis}

For the morphometrical analysis, rights testicles were collected and fixed in Bouin $75 \%$ saturated picric acid, 25\% formaldehyde, $5 \%$ glacial acetic acid) for $24 \mathrm{~h}$ and then transferred to a container with $70 \%$ ethanol. The material was dehydrated using the solutions of increasing concentrations of ethanol (80, 90, 95\% and absolute), diaphanized in xylene and embedded in paraffin.Sections of 5.0 $\mu \mathrm{m}$ were used for making the histological slides and stained with hematoxylin-eosin (Luna, 1968; Pannocchia et al. 2008). Images of histological slides were obtained in an image capture system consisting of binocular microscope (CX31, Olympus Optical of Brazil Ltda, São Paulo, Brazil) and capture camera of digital image (SC30, Olympus Optical of Brazil Ltda, São Paulo, Brazil).The images were captured from the 10x objective lens from each tissue animal at 15 different fields and analyzed with ImageJ software (NIH).

The average tube diameter and the height of the seminiferous epithelium were obtained for each animal from the measurement of 30 cross sections of seminiferous tubules contour as circular as possible, not taking into account the stage of the seminiferous epithelium cycle(Berndtson et al. 1989). The volumetric proportions of the various constituents of the testicular parenchyma, such as tubular magazine (lumen, epithelium and tunic) and intertubular compartment (Leydig cells, lymphatic breast, blood vessels and others) were evaluated from the point spread on tubule and intertubule graticule containing overlapping 432 points to images obtained in a total of 15 fields per segment per animal, chosen at random, totaling 6.480 points.

The volume $(\mathrm{mL})$ of each testicular component evaluated was estimated from the percentage occupied by them in the testis and net volume of the testicle. The value of the latter was obtained by subtracting the gross weight of the testis weight of the tunica albuginea. In adult rats, the weight of the tunica albuginea was considered to be $6.5 \%$ of the gross weight of the testicle (Russell and França 1995).The total length (meters) of the seminiferous tubules was estimated from the volume occupied by the seminiferous tubules in the testes and the mean tubular diameter obtained for each animal, using the formula $\mathrm{CT}=\mathrm{VTS} / \pi \mathrm{R}^{2}$ (VTS = total volume of seminiferous tubules; $\pi \mathrm{R}^{2}$ $=$ cross sectional area of the seminiferous tubules; $\mathrm{R}=$ tubular radius) (Attaland Courot 1963).

The individual volume of the Leydig cells was obtained from the core volume and the proportion of nucleus and cytoplasm. The core volume was obtained using core diameter average and 20 core diameters were evaluated for each animal. Individual nuclear volume obtained was expressed in $\left(\mu \mathrm{m}^{3}\right)$, using the formula $4 / 3 \pi \mathrm{R}^{3}, \mathrm{R}=$ nuclear diameter/2. To calculate the ratio between the nucleus and cytoplasm, graticule with 432 intersections (points) at $1000 \mathrm{x}$ was used. Approximately thousand points on Leydig cells were counted for each animal. The number of Leydig cells per gram of testis was estimated from the individual volume of Leydig cells and the volume occupied by the Leydig cells in the testis.

\section{Sperm quality analysis}

Immediately after euthanizing the animals, a cut of approximately $2.0 \mathrm{~mm}$ in thickness was performed on the right tail of the epididymis. The fragment obtained by cutting was incubated in a waterbath in $5.0 \mathrm{~mL}$ of TALP (Tyrode's Albumin - Lactate - Pyruvate) at $37^{\circ} \mathrm{C}$ for $10 \mathrm{~min}$ (Lotfi et al. 2013).

\section{Sperm motility (percentage of motile sperm)}

For this, $5.0 \mu \mathrm{L}$ of supernatant containing the sperm was placed between the slide and cover slip and observed at $100 \mathrm{x}$ in a negative phase contrast microscopy (CX31, Olympus Optical of Brazil Ltda, São Paulo, Brazil). The evaluation of the movement of the sperm was held in three different fields and motility was expressed from the middle of the fields in percentage of motile sperm of the total sperm counted (Badkoobeh et al. 2013).

\section{Sperm count $\left(\mathrm{x} 10^{6}\right.$ sperm $\left./ \mathrm{mL}\right)$}

For this, $10 \mu \mathrm{L}$ of the supernatant containing the epididymal sperm were diluted in $990 \mu \mathrm{L}$ of a solution of paraformaldehyde and sodium citrate. Approximately $10 \mu \mathrm{L}$ of diluted contents were 
transferred to a hemocytometer (Neubauer chamber), which was taken in light microscopy at $400 \mathrm{x}$. The pelleted cells were counted on the surface of the chamber. The calculation of the sperm concentration was performed according to the number of counted cells and hemocytometer dimensions. The concentration was expressed in millions of sperm per $\mathrm{mL}$ (Badkoobeh et al. 2013).

\section{Sperm morphology (percentage of normal cells)}

For the analysis of sperm morphology, a drop of about $20 \mu \mathrm{L}$ of sperm suspension was placed on the microscope slides and swiped. Slides were dried and stained with eosin-nigrosin (1\% eosin Y and 5\% nigrosine). After drying, they were observed in the optical microscopy (CX31, Olympus Optical of Brazil Ltda, São Paulo, Brazil) at 400x. Differential count of 200 spermatozoa per slide was performed and observed changes for head, middle piece and tail.The results were expressed as percentage of normal cells (Badkoobeh et al. 2013).

\section{Membrane integrity (Sperm viability)}

An aliquot of $20 \mu \mathrm{L}$ of the suspension containing the sperm was diluted with an equal volume of nigrosine-eosin (1\% eosin $\mathrm{Y}$ and $5 \%$ nigrosine). Then, a smear of content was carried out on the microscope slide and after drying, the preparations were evaluated in light microscopy (CX31, Olympus Optical do Brasil Ltda, São Paulo, Brasil) at 400x.Differential count of 200 spermatozoa was performed by observing the proportion of sperm unstained (full membrane, said as viable) on the colored (non-intact membrane, said as non-viable). Results were expressed as percentage of spermatozoa with intact membrane (viable) on total sperm counted (Badkoobeh et al. 2013).

\section{Statistical analysis}

Data were subjected to analysis of variance (ANOVA) after the Shapiro-Wilk and Bartlett tests be applied to verify the normality and homoscedasticity of variances. The treatments were compared to the control by Dunnett test. For the variable that did not obey the basic assumptions of analysis of variance (morphology), the nonparametric Kruskal-Wallis was used.The level of significance for the analyzes was set at $p<0.05$. All the analyzes were performed with the aid of $\mathrm{R}$ software and Multicomp package to perform the Dunnett test.

\section{RESULTS AND DISCUSSION}

The yields of hexanic, dicloromethanic, ethyl acetate, $n$-butanol, aqueous soluble in methanol and aqueous insoluble in methanol fractions were $52.29,7.51,6.18,1.65,30.84$ and $1.52 \%$, respectively. The dried residues were $86.06 \mathrm{~g}$ for hexanic fraction, $12.37 \mathrm{~g}$ for dicloromethanic fraction, $10.17 \mathrm{~g}$ for ethyl acetate fraction, $2.73 \mathrm{~g}$ for $n$-butanol fraction, 50.76 for aqueous soluble in methanol fraction and $2.51 \mathrm{~g}$ for aqueous insoluble in methanol fraction.

The results of this study for the analysis of biometric parameters of the animals showed that the average testes weights of the groups supplemented with ethanolic extract and aqueous soluble in methanol fraction of $T$. terrestris were higher $(\mathrm{p}<0.05)$ when compared to the control group.However, there were no changes ( $p>0.05$ ) in body weight of the groups studied. The GSI of the animals that received ethanol extract was higher $(p<0.05)$ than the control group (Table 1$)$. Changes in the absolute and relative weights of reproductive organs are evidence to initially classify a substance with possible reproductive potential (ZENICK et al. 1994). Work carried out by Cek et al. (2007)in fishes and Bashir et al. (2009)in rats found that the gonads of the experimental groups supplemented with $T$. terrestris were larger than the control group. These results were related to the possible effect of T. terrestris on spermatogenesis.

Regarding morphometric parameters of the gonads, there were no differences $(p>0.05)$ in diameter of the seminiferous tubules or in the percentage of seminiferous tubules per testis ( $p>0.05)$. However, a larger seminiferous epithelial height $(\mathrm{p}<0.05)$ as well as larger total tube length $(\mathrm{p}<0.05)$ was observed in the group that received the ethanol extract. The tubular volume $(\mathrm{mL})$ of all the experimental groups supplemented with the extract and $T$. terrestris fractions showed higher values $(\mathrm{p}<0.05)$ compared with the control group (Table 1). Wing and Christensen (1982) reported tubular diameter changes over the seminiferous tubule in the rats. Morais et al. (2009) suggested that the height of the seminiferous epithelium was influenced by the tubular peristalsis and that for methodological 
variations was probably a better parameter than the diameter tubular to evaluate the spermatogenic activity.

The length of the seminiferous tubules is related to three structural parameters: testicular weight, diameter of the seminiferous tubules and tubular volume (Souza et al. 2005). In this study, the animals supplemented with ethanol extract showed an increase in the total tube length and, as already discussed, also showed an increase in height of the seminiferous epithelium. The seminiferous tubules correspond to the location of occurrence of spermatogenesis, in which the diploid spermatogonia differentiate into a mature haploid cell, sperm (Russell et al. 1990).This process occurs in the seminiferous epithelium, therefore, an increase in the height of the seminiferous tubule epithelium may be an increase in the sperm production process.

Table 1 - Biometric and morphometric data of the testicles of Wistar rats supplemented with extracts and fractions of fruits of Tribulus terrestris (mean \pm standard deviation) $(\mathrm{n}=20)$.

\begin{tabular}{|c|c|c|c|c|}
\hline \multirow[b]{2}{*}{ Parameters } & \multicolumn{4}{|c|}{ Experimental groups } \\
\hline & Control & $\begin{array}{c}\text { Ethanolic } \\
\text { extract }\end{array}$ & $\begin{array}{l}\text { Hexanic } \\
\text { fraction }\end{array}$ & $\begin{array}{l}\text { Aqueous soluble in } \\
\text { methanol fraction }\end{array}$ \\
\hline Final body weight $(\mathrm{g})$ & $375.0 \pm 40.51$ & $360.4 \pm 45.93$ & $377.0 \pm 32.22$ & $416.8 \pm 59.81$ \\
\hline Testicular weight $(\mathrm{g})^{(1)}$ & $1.39 \pm 0.28$ & $2.09 \pm 0.13^{*}$ & $1.74 \pm 0.11$ & $1.89 \pm 0.36^{*}$ \\
\hline Gonadosomatic index $(\%)$ & $0.74 \pm 0.12$ & $1.18 \pm 0.18^{*}$ & $0.93 \pm 0.09$ & $0.93 \pm 0.24$ \\
\hline Diameter tubular $(\mu \mathrm{m})$ & $287.1 \pm 30.5$ & $286.5 \pm 26.2$ & $303.7 \pm 23.2$ & $294.6 \pm 10.0$ \\
\hline Height of seminiferous epithelium $(\mu \mathrm{m})$ & $69.0 \pm 4.5$ & $80.2 \pm 7.4^{*}$ & $66.3 \pm 7.5$ & $61.4 \pm 5.9$ \\
\hline Percentage of seminiferous tubules & $89.84 \pm 1.44$ & $86.5 \pm 3.47$ & $88.21 \pm 1.37$ & $84.57 \pm 3.04$ \\
\hline Tubular volume (mL) & $1.16 \pm 0.23$ & $1.69 \pm 0.08^{*}$ & $1.43 \pm 0.10^{*}$ & $1.49 \pm 0.24^{*}$ \\
\hline Full length tubular (m) & $18.18 \pm 4.31$ & $26.57 \pm 3.86^{*}$ & $20.03 \pm 3.20$ & $21.96 \pm 4.07$ \\
\hline \multicolumn{5}{|l|}{ Leydig cells: } \\
\hline Proportion of core $(\%)$ & $28.91 \pm 4.3$ & $27.45 \pm 3.31$ & $22.35 \pm 5.12$ & $25.6 \pm 3.27$ \\
\hline Nuclear volume $\left(\mu \mathrm{m}^{3}\right)$ & $85.0 \pm 16.3$ & $119.3 \pm 23.1$ & $155.1 \pm 31.0^{*}$ & $155.8 \pm 30.9^{*}$ \\
\hline Cytoplasmic volume $\left(\mu \mathrm{m}^{3}\right)$ & $214.1 \pm 58.8$ & $316.5 \pm 61.6$ & $568.1 \pm 218.4^{*}$ & $463.7 \pm 139.2^{*}$ \\
\hline Individual volume $\left(\mu \mathrm{m}^{3}\right)$ & $299.1 \pm 71.2$ & $435.8 \pm 79.7$ & $723.2 \pm 237.3^{*}$ & $619.4 \pm 165.2^{*}$ \\
\hline Leydig cells/g/testicles $\left(\times 10^{6}\right)$ & $21.5 \pm 5.2$ & $27.8 \pm 9.9$ & $15.3 \pm 4.2^{*}$ & $20.4 \pm 7.1$ \\
\hline
\end{tabular}

The percentage of seminiferous tubules in the testes usually is between 60 and $90 \%$ in most species (Setchell 1982). These values were in line with the results of this study and showed no changes between the groups. The volumetric proportion of testicular parenchyma components directly reflects the efficiency of sperm production (França and Russell 1998).

In the analysis of Leydig cells, the nuclear volume, cytoplasmic volume and cellular individual volume increased $(\mathrm{p}<0.05)$ in the groups supplemented with hexanic and aqueous soluble in methanol fractions. However, the hexanic fraction decreased $(p<0.05)$ the number of Leydig cells per gram of testis (Table 1). In intertubular compartment blood and lymph vessels, nerve cells and connective tissue fibers, macrophages, mast cells and Leydig cells are found. The latter produce androgens, which are responsible for the appearance of secondary sexual characteristics and the maintenance of spermatogenesis in sexually mature animals(Russell et al. 1990; França and Russell 1998). In this study, a significant increase in the nuclear volume, cytoplasm volume and consequently cellular individual volume could be related to the increased availability of testosterone. The supplementation of the extract and fractions of the fruit of $T$. terrestris did not show any change in the sperm quality (Table 2). However,Keshtmand et al. (2014)found an improvement in sperm quality as increasing the percentage of normal cells and the motile sperm adults mices treated with ethanolic extract of $T$. terrestris at the doses of 100,300 or $500 \mathrm{mg} \cdot \mathrm{kg}^{-1}$ on cytotoxicity on 
reproductive system induced by cisplatin, an antitumor drug, at a dose of $5.5 \mathrm{mg} . \mathrm{kg}^{-1}$. This species has several antioxidant chemicals that can protect the sperm plasma membrane against lipid peroxidation, reducing the percentage of dead spermatozoa and maintaining normal cell morphology.

Table 2 - Sperm quality of rats supplemented with extract and fractions of fruit of Tribulus terrestris (mean \pm standard deviation) $(\mathrm{n}=20)$.

\begin{tabular}{|c|c|c|c|c|}
\hline \multirow[b]{2}{*}{ Parameters } & \multicolumn{4}{|c|}{ Experimental groups } \\
\hline & Control & $\begin{array}{c}\text { Ethanolic } \\
\text { extract }\end{array}$ & Hexanic fraction & $\begin{array}{l}\text { Aqueous soluble in } \\
\text { methanol fraction }\end{array}$ \\
\hline Sperm motility (\% motile sperm) & $68 \pm 10.37$ & $62 \pm 25.15$ & $51 \pm 26.78$ & $73 \pm 19.87$ \\
\hline Sperm count $\left(x 10^{6}\right.$ sperm $\left./ \mathrm{mL}\right)$ & $90 \pm 41.83$ & $80 \pm 44.72$ & $80 \pm 27.39$ & $60 \pm 22.36$ \\
\hline Sperm morphology (\% normal cells) & $97.2 \pm 0.84$ & $97.4 \pm 1.14$ & $93.8 \pm 4.66$ & $94.4 \pm 3.65$ \\
\hline Sperm viability (\% viable sperm) & $71.6 \pm 14.9$ & $80.2 \pm 13.5$ & $66.4 \pm 15.8$ & $70.2 \pm 14.1$ \\
\hline
\end{tabular}

Other work done to evaluate the sperm quality of the rats was performed by Elahi et al. (2013). The control group received distilled water and sugar and two groups received 5.0 or $10 \mathrm{mg} \cdot \mathrm{kg}^{-1}$ of a solution of $T$. terrestris for eight weeks. The study showed that a higher sperm count and increased maturity of them at a dose of $5 \mathrm{mg} \cdot \mathrm{kg}^{-1}$, in addition to reducing the number of malformed sperm compared with others groups. These results suggested that $T$. terrestris improved related parameters in males fertility, such as higher concentration of sperm, membrane integrity, highest percentage of mobile sperm and increased seminal volume.

In this study, crude extract and fractions was used, which could have antagonistic effects due to the presence of chemical compounds that led to such a condition. Many of these compounds might have effects by inhibiting or reducing the pharmacological activity of others. In addition, the presence of different chemotypes of $T$. terrestris could explain why it was not possible to obtain improvements in the quality of sperm parameters as reported by other authors. Furthermore, there was no standardization of the plant drug and some studies used all aerial parts of the plant (leaves, stems, flowers and fruits).

\section{CONCLUSIONS}

It was concluded that the ethanol extract of $T$. terrestris L. influenced the spermatogenesis as shown by the changes evident in the tubular compartment of the testes such as increase in the total tube length, tubular volume and height of the seminiferous epithelium. The hexanic and aqueous soluble in methanol fractions promoted the changes in intertubular compartment because they increased the nuclear volume, cytoplasmic volume and individual volume of Leydig cells. However, the extract and fractions of $T$. terrestris fruit did not improve sperm quality in male Wistar rats.

\section{ACKNOWLEDGMENTS}

The authors thank Coordenação de Aperfeiçoamento de Pessoal de Nível Superior (CAPES) and CNPq for financial support.

\section{REFERENCES}

Amann RP. Sperm production rates. The testis. New York: Academic; 1970.

Andrade AJM, Morais RN, Spercoski KM, Rossi SC, Vechi MF, Golin M, et al. Effects of Tribulus terrestris on endocrine sensitive organs in male and female wistar rats. JEthnopharmacol. 2010; 127: 165170.

Attal J, Courot M. Développement testiculaire et établissement de la spermatogénèse chez le taureau. Ann Biol Anim Bioch Biophys. 1963; 3(3): 219-241.

Badkoobeh P, Parivar K, Kalantar SM, Hosseini SD, Salabar A. Effect of nano-zinc oxide on doxorubicininduced oxidative stress and sperm disorders in adult male Wistar rats. Iran J Reprod Med. 2013;11(9): 355-364.

Bashir A, Tahir M, Munir B. Effects of Tribulus terrestris on testicular development of immature albino rats. Biomedica. 2009; 25(5): 63-68. 
Bedir E, Khan IA. New steroidal glycosides from the fruits of Tribulus terrestris. JN Prod. 2000;63(12): 1699-1701.

Berndtson WE, Neefus C, Foote RH, Amann RP. Optimal replication for histometric analyses of testicular function in rats or rabbits. Fund App Toxicol.1989;12(2): 291-302.

Cek S, Turan F, Atik E. Masculinization of convict cichlid (Cichlasoma nigrofasciatum) by immersion in Tribulus terrestris extract. Aquacult Int. 2007; 15(2): 109-119.

Dinchev D,Janda B, Evstatieva L, Oleszek W, Aslani MR, Kostova I. Distribution of steroidal saponins in Tribulus terrestris from different geographical regions. Phytochemistry. 2008;69: 176-186.

Elahi RK, Asl S, Shahian F. Study on the effects of various doses of Tribulus terrestris extract on epididymal sperm morphology and count in rat. Glob Veterin. 2013;10: 13-17.

França LR, Russell LD. The testis of domestic mammals. Madrid: Churchill Communications Europe España; 1998.

Gauthaman K, Adaikan PG, Prasad RNV. Aphrodisiac properties of Tribulus terrestris extract (Protodioscin) in normal and castrated rats. Lif Scienc. 2002;71(12): $1385-1396$

Gauthaman K, Ganesan AP. The hormonal effects of Tribulus terrestris and its role in the management of male erectile dysfunction - An evaluation using primates, rabbit and rat. Phytomed. 2008;15(1-2): 4454.

Hammoda HM, Ghazy NM, Haraz FM, Radwan MM, ElSohly MA, Abdallah II, Chemical constituents from Tribulus terrestris and screening of their antioxidant activity. Phytochem. 2013; 92: 153-159.

Keshtmand Z, Oryan S, Ghanbari A, Khazaei M. Protective effect of Tribulus terrestris hydroalcoholic extract against cisplatin-induced cytotoxicity on sperm parameters in male mice. Int $J$ Morphol. 2014;32(2): 551-557.

Kostova I, Dinchev D. Saponins in Tribulus terrestris chemistry and bioactivity. Phytochem Rev. 2005; 4(23): 111-137.

Lotfi N, Khazaei M, Shariatzadeh SMA, Mehranjani MS, Ghanbari A.The effect of Cannabis sativa hydroalcoholic extract on sperm parameters and testis histology in rats. IntJ Morphol.2013;31:82-86.

Luna, L. G. Manual of histology stainig methods of the Armed Forces Institute of Pathology. New York: McGraw-Hill; 1968.
Morais ACT, Barbosa LP, Neves MM, Matta SLP, Morais DB, Melo BES. Parâmetros morfofisiológicos testiculares de camundongos (Mus musculus) suplementados com geleia real. Arq Bras Med Vet Zootec. 2009;61: 110-118.

Neychev VK, Mitev VI. The aphrodisiac herb Tribulus terrestris does not influence the androgen production in young men. J Ethnopharmacol. 2005; 101 (1-3): 319-323.

Pannocchia MA, Borella MI, Camargo ACM, Gilio JM, Silva CA. Estratégia efetiva de fixação do testículo de ratos Wistar para avaliar os parâmetros morfológicos e morfométricos do epitélio seminífero. ConScient Saud. 2008; 7(2): 227-233.

Russell LD, Ettlin RA, Sinha Hikim AP. Histological and Histopathological Evaluation of the Testis. Clearwater: Cache River Press; 1990.

Russell LD, França, LR. Building a testis. Tiss Cell. 1995; 27: 129-147.

Sellandi TM, Thakar AB, Baghel MS. Clinical study of Tribulus terrestris Linn. in oligozoospermia: A double blind study. Clin Researc.2012;33(3): 356364.

Setchell BP. Reproduction in Mammals I. Cambridge: Cambridge University; 1982.

Singh S, Gupta YK. Aphrodisiac activity of Tribulus terrestris Linn. in experimental models in rats. $J M H$. 2011; 8: S75-S77.

Souza PC, Paula TAR, Natali AJ, Matta SLP, Costa DS, Fonseca CC, et al. Efeito do exercício crônico voluntário e do sedentarismo, com e sem o uso do esteroide anabólico nandrolona, sobre os componentes do parênquima testicular de ratos adultos. Ceres. 2005;53(300): 305-316.

Su L, Chen G, Feng SG, Wang W, Li ZF, Chen H, Liu YX, Pei YH.Steroidal saponins from Tribulus terrestris. Steroids. 2009; 74 (4-5): 399-403.

Wing TY, Christensen AK. Morphometric studies on rat seminiferous tubule. Am J Anat. 1982; 165: 13-25.

Zenick H.Principles and methods of toxicology. 3 ed. New York: CRC;1994.
Received: May 13, 2015; Accepted: August 17, 2015. 